\title{
Syntactic complexity in Iranian learners' English writing and speaking
}

\author{
Sarah Yazdani \\ yazdani.sarah@mail.um.ac.ir \\ Linguistics department, Ferdowsi University of Mashhad \\ Faculty of Letters and Humanities, Ferdowsi University of Mashhad, Park Square, \\ Mashhad, Iran
}

Received: November 22, 2017; $\quad$ Accepted: January 11, 2018; $\quad$ Published: March 2, 2018

\begin{abstract}
This study is aimed at demonstrating the use of syntactic complexity in Iranian learners' English written and spoken discourse using quantitative-qualitative approach. To fulfill this purpose, forty-five female Iranian students from 3 branches of a private language institute in Mashhad were recruited. The subjects were divided into three groups based on Cambridge Placement Test results: elementary, intermediate, and advanced. All groups (each 15 participants) were asked to write a 200-word essay on a topic. Thereafter, the essays were examined manually for the T-units according to the classification used by the experts. In the follow-up phase of the study, participants were asked to attend an interview on the same topic of their writings to evaluate the usage of $\mathrm{C}$-units in their speaking. The findings illustrate the fact that the most frequent element in macro level was clause in both writing and speaking, while in micro level, there were significant differences between elementary group \& intermediate group and between the elementary group and advanced group in writing skill and there was a significant difference between elementary group \& advanced group in using subordinate clauses in speaking. A future study investigating syntactic complexity in other skills such as reading would be very interesting.
\end{abstract}

Keywords: syntactic complexity, Iranian learners, T-units, C-units, English writing and speaking 
How to cite this paper: Yazdani, S. (2018). Syntactic complexity in Iranian learners' English writing and speaking. Journal on English as a Foreign Language, 8(1), 75-96 (doi: 10.23971/jefl.v8i1.718)

DOI: http://dx.doi.org/10.23971 jefl.v8i1.718

Among most of the linguists, various types of units used by writer or speaker make communication possible. These dependencies which are created by syntactic units contribute to producing and comprehending a language. These units somewhat clarify the improvement of target language and come in multiple forms such as T-unit, C-unit, AS-unit, U-unit and so on. The present study is focused on T-unit and C-unit. T-unit (Larsen-Freeman 2006; Armstrong, 2010) consists of the main clause in addition to any subordinate clause which is attached to it. A communication unit which is also called a Cunit contains a main clause plus at least one dependent clause which might be a subordinate clause, nonfinite clause or double embedded clause. Each of these dependent clauses includes several subgroups which are explained in the next section.

Syntactic complexity is an ongoing concern in the field of language learning improvement. This issue has received considerable attention from researchers (e.g., Beers \& Nagy, 2011; Lu, 2010; Rimmer, 2008; Ortega, 2003). In Iran, students are going through a hard time of learning English, since the only way to access an environment for practicing is foreign language institutes. Therefore, developing and improving language learning skills, particularly productive skills such as writing and speaking need extra attention. Using complex structures to talk or write about a subject will help the learner to explain the inputs efficaciously. On the other hand, some scholars claim that using simple structures is a signal of the learner's weakness (see, e.g., Hinkel, 2003); since constructing complex sentences might cause problems and act like a barrier for Iranian learners.

Most studies on syntactic complexity have only focused on second language learning and mostly evaluated writing improvement among leaners (see, e.g., Taguchi, Crawford \& Wetzel, 2013; Low, 2011; Connors, 2000). Therefore, the generalization of the results of published studies to this subject is problematic; due to the fact that too little attention has been paid to syntax growth among Iranian learners who learn English as a foreign language. Therefore, the aim of this study is to shed more light on the debates through an examination of the usage of T-unit, C-unit and their types in different levels of English writing and speaking of Iranian learners. 
The present study seeks to address the following questions:

1. What is the frequency of T-units in different levels of Iranian learners' English writing in macro structure?

2. Is there any significant difference in using T-units in different levels of Iranian learners' English writing in micro structure?

3. What is the frequency of C-units in different levels of Iranian learners' English speaking in macro structure?

4. Is there any significant difference in using C-units in different levels of Iranian learners' English speaking in micro structure?

The overall structure of this study consists of five sections, including the introductory part. In the following, section two will begin by laying out the theoretical dimensions of the research and looks at how syntactic complexity is evaluated in second language acquisition. The third section is concerned with the methodology used for this study. The fourth section presents the findings of the research. The next section will analyze and discuss the results of usage of Tunit, C-unit and their types in learners' writing and speaking. Finally, the conclusion gives a brief summary as well as the implication of the findings to the pertinent future studies.

In 1964, Hunt introduced a new term for measuring complexity in syntactic structures in writing. He labeled this linguistic means as "T-unit" which is also called "terminable unit". The T-unit comprises of the main clause and any subordinate clauses attached to or embedded in it.

E. g.: The man who lives next door is my uncle. (1 T-unit)

Hunt asserted that a T-unit length signals the advancement of cognition in children and the analysis of T-unit provides a solid and reliable indicator of language improvement.

Furthermore, the preliminary work on language assessment by Greenbaum and Quirk in 1991-which also takes speaking into account, was done by. It showed that "C-unit" or "communication unit" could be used to measure syntactic complexity in speaking. C-unit is described as main clause plus its modifiers.

E.g.: Mary became very upset when she found out that she missed the train.

(3 C-units, one main clause and 2 subordinate clauses)

One should bear in mind that $\mathrm{C}$-unit and T-unit are indistinguishable, except for the fact that $\mathrm{C}$-unit is an incomplete sentence as an answer to question. E.g.: How often do you play badminton? About three times a week (1 C-unit) A considerable amount of research has been published on syntactic complexity. These studies have focused on second language learning improvement. Domsch, Richels, Saldana, Coleman, Wimberly, and Mazwell (2012) analyzed the data from 22 eight years old children with "Late Language Emergence" 
(LLE), who were divided into 2 groups and compared with a group of 11 children with "Typical Development" (TD). The participants were asked to complete a narrative and a conversational test. Afterward, they measured the application of syntactic and lexical complexity in two groups. The results indicated the fact that the production and comprehension scores of children diagnosed with LLE were identical to children with typical improvement in the narrative test. While the performance of children with LLE showed fewer complex sentences.

Similarly, in order to measure the impact of the complexity of syntax, reversibility of semantics and explicitness on comprehension of discourse, Levy, Hoover, Beradino, and Sardberg (2012) compared persons with Aphasia (PWA) with healthy individuals. 38 PWA and a group of 30 healthy participants were instructed to listen to several passages contained 2-3 syntactically simple or complex reversible sentences. They were supposed to answer 4 multiple choice questions after hearing each passage. The results of their study verified the fact that the syntactically complex sentences were difficult for PWA to comprehend, as they provided better and more accurate answers to the questions that needed syntactically simple sentences.

Nevertheless, much of the research that have been done in Iran up to now has been descriptive in nature of syntactic structures in Iranian English written or spoken discourse (e.g., Javidnia \& Mahmoodi, 2015; Moghtadi, Koosha \& Lotfi, 2015; Mohammadi, Gorjian \& Pazhakh, 2014; Khodabandeh, Jafarigohar, Soleimani \& Hemmati, 2013; \& Mehregan, 2013 ). In addition, no research has been found in Iran that surveys the improvement of syntactic complexity in learners' English writing and speaking.

Overall, these studies highlight the need for investigating syntactic complexity in different stages of language learning. However, these studies have failed to specify the in-depth analysis of such structures among Iranian learners. Thus, the present study will give an account of syntactic improvement in Iranian learners' English writing and speaking.

\section{METHOD}

It was decided that the best method to adopt for this investigation was to use quantitative-qualitative approach to provide an exhaustive analysis (see, e.g., Maxwell \& Loomis, 2003). Based on Morgan's table (1970) of sample size, forty-five Iranian students from 3 branches of one of the private language institutes (KLI) in Mashhad were recruited for this study. All of them were female and their first language was Persian. The selection was based on convenience sampling. The subjects were divided into three groups on the basis of degree of homogeneity of their Cambridge Placement Test results: group A) 
elementary, aged between 9 and 13 years $(M=10.93, S D=1.53)$, group B) Intermediate, aged between 14 and 18 years $(\mathrm{M}=16.13, \mathrm{SD}=1.59)$ and group $\mathrm{C})$ advanced, aged between 19 and 25 years $(\mathrm{M}=21.53, \mathrm{SD}=1.99)$. Each group consisted of 15 participants.

In order to have a homogenous sample, Cambridge Placement Test was run before the study. The subjects were asked to answer the questions within 45 minutes. Participants' proficiency level was determined via the number of correct answers. In other words, 20-39 correct answers mark participants as elementary, 60-80 correct answers signal subjects as Intermediate and to be in the advanced group, participants had to answer 100-120 questions correctly. After the test results and group division (group A, B \& C), a topic was given to the participants to measure the usage of T-units in their writing. In the followup phase of the study, participants were asked to attend an interview. The interview included the same topic of their writings coupled with several related questions to evaluate the usage of $\mathrm{C}$-units in their speaking.

Procedures for research are: First, the Cambridge Placement Test was used for homogeneity of population. Then, the eligible participants were selected based on availability and were assigned into 3 groups, each consisted of 15 learners. All groups were asked to write a 200 words essay about this topic "People attend college or university for many different reasons (for example, new experiences, career preparation, increased knowledge). Why do you think people attend college or university? Use specific reasons and examples to support your answer." The time considered for this task was 60 minutes, in line with the normal class time assigned to longer writing tasks. Thereafter, the essays were examined manually for the T-units. T-units were analyzed according to the classification suggested by Norris and Ortega (2009). Based on their model, the measurement of T-units is divided into 2 major classes, (1) macro structures in which productivity is examined through the evaluation of mean length of sentence, clause and T-unit (for writing analysis) and C-unit (for speaking analysis), (2) micro-structures that break down into 3 groups: (a) coordination, (b) subordination, and (c) complex T-unit.

Subsequently, each of these groups was asked to take part in an interview a week later. During the interview which lasted 15 to 20 minutes for each participant, the same topic of their writing was asked with several related questions. The data was recorded on a digital audio recorder (Sony ICD-UX533) and then transcribed. The recording was done in the supervisor's office to eliminate the extra noise and sound from outside. During the recording, it was tried to keep the reorder stable and the distance between the recorder and the participants' mouth was $25 \mathrm{~cm}$. The transcription of the interviews and the essays were scrutinized to find the C-units. C-units were analyzed using the 
similar method that was detailed for T-units, using the model reported by Greenbaum and Quirk in 1991. Then C-unit was grouped into two types: (1) coordination and (2) subordination.

The uncompleted and ungrammatical sentences or those which contained spelling errors were excluded from the study. In order to increase the reliability of the measures, 3 female raters, aged between 25 to 35 years, who majored in linguistics, were asked to check the papers again to ensure the results.

\section{FINDINGS}

The first step in analyzing the data was to use Kolmogorov-Smirnov test to confirm the normal distribution of the data in all categories. The results obtained from this test showed that the normal distribution was normal in all the variables $(p>0.05)$. To determine the probable significant differences in macro categories of writings of Iranian learners among three groups, one-way ANOVA was run (Tables 1 and 2).

Table 1. Descriptive Tables of T-units in Writing (Macro)

\begin{tabular}{ccccccc}
\hline Group & $\begin{array}{c}\text { Macro } \\
\text { categories }\end{array}$ & $\mathrm{N}$ & Mean & $\begin{array}{c}\text { Std. } \\
\text { deviation }\end{array}$ & $\begin{array}{c}\text { Maximum } \\
\text { No. }\end{array}$ & $\begin{array}{c}\text { Minimum } \\
\text { No. }\end{array}$ \\
\hline Elementary & Clause & 15 & 12.80 & 4.16 & 5.00 & 22.00 \\
& Sentence & 15 & 7.53 & 2.97 & 3.00 & 15.00 \\
& T--unit & 15 & 5.86 & 2.35 & 2.00 & 11.00 \\
\hline Intermediate & Clause & 15 & 17.06 & 4.28 & 10.00 & 23.00 \\
& Sentence & 15 & 9.80 & 2.48 & 6.00 & 14.00 \\
& T-unit & 15 & 11.33 & 3.94 & 4.00 & 17.00 \\
\hline Advanced & Clause & 15 & 24.86 & 8.45 & 12.00 & 35.00 \\
& Sentence & 15 & 15.13 & 5.64 & 6.00 & 25.00 \\
& T-unit & 15 & 24.20 & 15.98 & 10.00 & 77.00 \\
\hline
\end{tabular}

A one- way ANOVA analysis revealed that the results were significant at $\mathrm{p}<05$ level of significance among three groups in using macro structures. It is apparent from the tables 1 and 2 that there is a significant difference in using clauses (Mean=18.24, SD=7.71), sentences (Mean=10.82, SD=5.02) and T-units (Mean=13.80, SD=12.18) in Iranian learners' English writing. 
Table 2. Descriptive tables of T-units in writing between \& within groups (Macro)

\begin{tabular}{|c|c|c|c|c|c|c|}
\hline $\begin{array}{c}\text { Macro } \\
\text { categories }\end{array}$ & $\mathrm{F}$ & Sig & Group & $\begin{array}{l}\text { Sum of } \\
\text { squares }\end{array}$ & Df & Mean square \\
\hline \multirow[t]{3}{*}{ Clause } & 15.735 & .000 & $\begin{array}{l}\text { Between } \\
\text { group }\end{array}$ & 1123.244 & 2 & 561.622 \\
\hline & & & Within group & 1499.067 & 42 & 35.692 \\
\hline & & & Total & 2622.311 & 44 & \\
\hline \multirow[t]{3}{*}{ Sentence } & 14.623 & .000 & $\begin{array}{l}\text { Between } \\
\text { group }\end{array}$ & 456.711 & 2 & 228.356 \\
\hline & & & Within group & 655.867 & 42 & 15.616 \\
\hline & & & Total & 1112.578 & 44 & \\
\hline \multirow[t]{3}{*}{ T-unit } & 14.409 & .000 & $\begin{array}{l}\text { Between } \\
\text { group }\end{array}$ & 2657.733 & 2 & 1328.867 \\
\hline & & & Within group & 3873.467 & 42 & 92.225 \\
\hline & & & Total & 6531.200 & 44 & \\
\hline
\end{tabular}

To compare the mean of usage of macro structures among the aforementioned groups, Multiple Comparisons Tukey HSD was used. This test specifies the significant differences in detail among three groups. The results are displayed in table 3.

Table 3. Multiple Comparisons Tukey HSD among 3 Groups in Writing (Macro)

\begin{tabular}{cccc}
\hline Category & Group & Mean difference & Sig \\
\hline Clause & $\begin{array}{c}\text { Elementary \& } \\
\text { Intermediate } \\
\text { Elementary \& } \\
\text { Advanced } \\
\text { Intermediate \& } \\
\text { Advanced }\end{array}$ & -4.26 & .136 \\
\hline Sentence & $\begin{array}{c}\text { Elementary \& } \\
\text { Intermediate } \\
\text { Elementary \& } \\
\text { Advanced } \\
\text { Intermediate \& } \\
\text { Advanced }\end{array}$ & -2.000 & .003 \\
\hline T-unit & $-7.60^{*}$ & .269 \\
& $\begin{array}{c}\text { Elementary \& } \\
\text { Intermediate } \\
\text { Elementary \& } \\
\text { Advanced } \\
\text { Intermediate \& } \\
\text { Advanced }\end{array}$ & $-5.33^{*}$ & .000 \\
\hline
\end{tabular}

*significance at the 0.05 level 
The most striking observation that emerged from comparing the data was that there were significant differences among the elementary \& advanced groups and intermediate \& advanced groups $(\mathrm{p}=0.000, \mathrm{p}<0.05)$, while no significant difference was found among the elementary \& intermediate groups in using macro structures in Iranian students' English writing.

To designate the probable significant differences in micro categories of Iranian learners' English writings among three groups, a one-way ANOVA was run for the second time. Tables 4 and 5 show the results.

Table 4. Descriptive Tables of T-units' Sub-division in Writing (Micro)

\begin{tabular}{ccccccc}
\hline Group & Micro categories & $\mathrm{N}$ & Mean & $\begin{array}{c}\text { Std. } \\
\text { deviation }\end{array}$ & $\begin{array}{c}\text { Maximu } \\
\mathrm{m} \text { No. }\end{array}$ & $\begin{array}{c}\text { Minimum } \\
\text { No. }\end{array}$ \\
\hline Elementary & Coordination & 15 & 4.71 & 1.32 & 2.00 & 7.00 \\
& $\begin{array}{c}\text { Subordination } \\
\text { Complex }\end{array}$ & 15 & 1.81 & .87 & 1.00 & 3.00 \\
& T-unit & & 1.00 & .01 & 1.00 & 1.00 \\
\hline Intermediate & Coordination & 15 & 5.53 & 2.97 & 1.00 & 12.00 \\
& Subordination & 15 & 3.86 & 1.64 & 2.00 & 7.00 \\
& Complex & 15 & 2.41 & 1.31 & 1.00 & 5.00 \\
& T-unit & & & & & \\
\hline Advanced & Coordination & 15 & 9.40 & 3.66 & 5.00 & 17.00 \\
& Subordination & 15 & 6.00 & 2.59 & 2.00 & 10.00 \\
& Complex & 15 & 5.46 & 1.72 & 3.00 & 9.00 \\
& T-unit & & & & & \\
\hline
\end{tabular}

Table 5. Descriptive Tables of T-units' Sub-division in Writing between \& within Groups (Micro)

\begin{tabular}{|c|c|c|c|c|c|c|}
\hline Group & $\mathrm{F}$ & Sig & Micro categories & $\begin{array}{l}\text { Sum of } \\
\text { Squares }\end{array}$ & $\mathrm{df}$ & $\begin{array}{l}\text { Mean } \\
\text { square }\end{array}$ \\
\hline Coordination & 11.314 & .000 & $\begin{array}{c}\text { Between groups } \\
\text { Within groups } \\
\text { Total }\end{array}$ & $\begin{array}{l}184.446 \\
334.190 \\
518.636\end{array}$ & $\begin{array}{c}2 \\
41 \\
43\end{array}$ & $\begin{array}{c}92.223 \\
8.151\end{array}$ \\
\hline Subordination & 15.301 & .000 & $\begin{array}{c}\text { Between groups } \\
\text { Within groups } \\
\text { Total }\end{array}$ & $\begin{array}{l}112.240 \\
139.370 \\
251.610\end{array}$ & $\begin{array}{c}2 \\
38 \\
40\end{array}$ & $\begin{array}{c}56.120 \\
3.668\end{array}$ \\
\hline $\begin{array}{c}\text { Complex } \\
\text { T-unit }\end{array}$ & 17.156 & .000 & $\begin{array}{c}\text { Between groups } \\
\text { Within groups } \\
\text { Total }\end{array}$ & $\begin{array}{c}80.040 \\
60.650 \\
140.690\end{array}$ & $\begin{array}{c}2 \\
26 \\
28\end{array}$ & $\begin{array}{c}40.020 \\
2.333\end{array}$ \\
\hline
\end{tabular}

The second one- way ANOVA analysis indicated that the results were significant at the $p<0.05$ level among three groups in using micro structures. 
Data analysis in tables 4 and 5 indicates a significant difference in using coordination (Mean=6.59, $\mathrm{SD}=3.47$ ), subordination (Mean=4.09, $\mathrm{SD}=2.50$ ) and complex T-unit (Mean=3.89, SD=2.24) in learners' English writing.

Similar to the macro structures inquiry, the Multiple Comparisons Tukey HSD was used to explain the differences elaborately among the three groups. The results are displayed in table 6.

Table 6. Multiple Comparisons Tukey HSD among 3 Groups in Writing (Micro)

\begin{tabular}{cccc}
\hline Category & Group & Mean difference & Sig \\
\hline Coordination & $\begin{array}{c}\text { Elementary \& } \\
\text { Intermediate } \\
\text { Elementary \& } \\
\text { Advanced } \\
\text { Intermediate \& } \\
\text { Advanced }\end{array}$ & -.819 & .722 \\
& $-3.68^{*}$ & .000 \\
\hline Subordination & $\begin{array}{c}\text { Elementary \& } \\
\text { Intermediate } \\
\text { Elementary \& } \\
\text { Advanced } \\
\text { Intermediate \& } \\
\text { Advanced }\end{array}$ & $-2.04^{*}$ & .002 \\
& $\begin{array}{c}\text { Elementary \& } \\
\text { Intermediate } \\
\text { Elementary \& } \\
\text { Advanced } \\
\text { Intermediate \& } \\
\text { Advanced }\end{array}$ & $-2.13^{*}$ & .028 \\
& -000 & .011 \\
\hline
\end{tabular}

*significance at the 0.05 level

Interestingly, in terms of using coordination and complex T-unit, there were significant differences between the elementary \& advanced groups and intermediate \& advanced groups ( $p=0.000, p<0.05)$; whereas the difference was not significant between the elementary \& advanced groups.

In applying subordination, Iranian students' English writing signaled significant differences between elementary \& intermediate groups and elementary \& advanced groups ( $\mathrm{p}=0.000, \mathrm{p}<0.05$ ). By contrast, no difference was detected between intermediate \& advanced Iranian learners.

Having presented the results of data analysis for complexity units in writing among Iranian learners, the same procedure was done for examining the macro and micro structures in speaking. The one-way ANOVA was used to identify the probable significant differences in macro categories of Iranian 
learners' English speaking among three groups. Tables 7 and 8 provide the results.

Table 7. Descriptive Tables of C-units in Speaking (Macro)

\begin{tabular}{ccccccc}
\hline Group & $\begin{array}{c}\text { Micro } \\
\text { categories }\end{array}$ & $\mathrm{N}$ & Mean & $\begin{array}{c}\text { Std. } \\
\text { deviation }\end{array}$ & $\begin{array}{c}\text { Maximum } \\
\text { No. }\end{array}$ & $\begin{array}{c}\text { Minimum } \\
\text { No. }\end{array}$ \\
\hline Elementary & Clause & 15 & 4.26 & 1.79 & 2.00 & 8.00 \\
& Sentence & 15 & 3.66 & 1.63 & 1.00 & 6.00 \\
& C-unit & 15 & 2.06 & 1.22 & 1.00 & 5.00 \\
\hline Intermediate & Clause & 15 & 8.93 & 1.33 & 6.00 & 11.00 \\
& Sentence & 15 & 6.26 & 1.27 & 4.00 & 9.00 \\
& C-unit & 15 & 4.80 & 1.01 & 4.00 & 7.00 \\
& & & & & & \\
\hline \multirow{2}{*}{ Advanced } & Clause & 15 & 8.20 & 1.74 & 6.00 & 13.00 \\
& Sentence & 15 & 6.93 & 2.37 & 4.00 & 11.00 \\
& C-unit & 15 & 5.40 & 1.76 & 3.00 & 9.00 \\
\hline
\end{tabular}

Table 8. Descriptive Tables of C-units in Speaking between \& within Groups (Macro)

\begin{tabular}{|c|c|c|c|c|c|c|}
\hline Group & $\mathrm{F}$ & Sig & $\begin{array}{c}\text { Micro } \\
\text { categories }\end{array}$ & $\begin{array}{l}\text { Sum of } \\
\text { Squares }\end{array}$ & $\mathrm{df}$ & $\begin{array}{l}\text { Mean } \\
\text { square }\end{array}$ \\
\hline \multirow[t]{3}{*}{ Clause } & \multirow{3}{*}{35.341} & \multirow{3}{*}{.000} & $\begin{array}{l}\text { Between } \\
\text { groups }\end{array}$ & 188.933 & 2 & 94.467 \\
\hline & & & $\begin{array}{l}\text { Within } \\
\text { groups }\end{array}$ & 112.267 & 42 & 2.673 \\
\hline & & & Total & 301.200 & 44 & \\
\hline \multirow[t]{3}{*}{ Sentence } & \multirow{3}{*}{13.484} & \multirow{3}{*}{.000} & $\begin{array}{l}\text { Between } \\
\text { groups }\end{array}$ & 89.378 & 2 & 44.689 \\
\hline & & & $\begin{array}{l}\text { Within } \\
\text { groups }\end{array}$ & 139.200 & 42 & 3.314 \\
\hline & & & Total & 288.578 & 44 & \\
\hline \multirow[t]{3}{*}{ C-unit } & \multirow{3}{*}{25.198} & \multirow{3}{*}{.000} & $\begin{array}{l}\text { Between } \\
\text { groups }\end{array}$ & 94.711 & 2 & 47.356 \\
\hline & & & $\begin{array}{l}\text { Within } \\
\text { groups }\end{array}$ & 78.933 & 42 & 1.879 \\
\hline & & & Total & 173.644 & 44 & \\
\hline
\end{tabular}

Tables 7 and 8 are good illustrations of significant differences among these three groups ( $\mathrm{Sig}=0.000<0.05$ ) in employing macro structures in speaking. The one- way ANOVA analysis showed this difference clearly in using clauses $(M=7.13, S D=2.61)$, sentences $(M=5.62, S D=2.27)$ and $C$-units $(\mathrm{M}=4.08, \mathrm{SD}=1.98)$ in Iranian learners' English speaking. 
To assess the application of macro structures in speaking among the mentioned groups elaborately, Multiple Comparisons Tukey HSD was used. Table 9 summarizes the results of the analysis.

Table 9. Multiple Comparisons Tukey HSD among 3 Groups in Writing (Macro)

\begin{tabular}{cccc}
\hline Category & Group & Mean difference & Sig \\
\hline Clause & $\begin{array}{c}\text { Elementary \& } \\
\text { Intermediate } \\
\text { Elementary \& } \\
\text { Advanced } \\
\text { Intermediate \& } \\
\text { Advanced }\end{array}$ & $-4.66^{*}$ & .000 \\
\hline Sentence & $\begin{array}{c}\text { Elementary \& } \\
\text { Intermediate } \\
\text { Elementary \& } \\
\text { Advanced } \\
\text { Intermediate \& } \\
\text { Advanced }\end{array}$ & $-2.93^{*}$ & .443 \\
\hline C-unit & $-3.26^{*}$ &. .001 \\
& $\begin{array}{c}\text { Elementary \& } \\
\text { Intermediate } \\
\text { Elementary \& } \\
\text { Advanced } \\
\text { Intermediate \& } \\
\text { Advanced }\end{array}$ & -.666 & .000 \\
\hline
\end{tabular}

*. The mean difference is significant at the 0.05 level.

What is provoking in these data is the significant differences between the elementary group \& intermediate group and between elementary group \& advanced group $(\mathrm{p}=0.000, \mathrm{p}<0.05)$, whereas no significant difference was detected in using macro structures between the intermediate group \& advanced group in Iranian students' English speaking.

A one-way ANOVA was run to set out the plausible significant differences among three groups in using micro categories among Iranian learners' English speaking. The results obtained from the analysis are presented in tables 10 and 11.

From tables 10 and 11 it is observed that no significant differences were found among Iranian speakers in using coordination (Mean=2.15, SD=1.24), while the difference (Mean=2.55, $\mathrm{SD}=1.30$ ) in using subordination in English speaking was significant $(\mathrm{p}=0.001, \mathrm{p}<0.05)$. 
Table 10. Descriptive Tables of C-units' Sub-division in Speaking (Micro)

\begin{tabular}{ccccccc}
\hline \multicolumn{1}{c}{ Group } & $\begin{array}{c}\text { Micro } \\
\text { categories }\end{array}$ & $\mathrm{N}$ & Mean & $\begin{array}{c}\text { Std. } \\
\text { deviation }\end{array}$ & $\begin{array}{c}\text { Maximum } \\
\text { No. }\end{array}$ & $\begin{array}{c}\text { Minimum } \\
\text { No. }\end{array}$ \\
\hline Elementary & Coordination & 15 & 1.73 & .798 & 1.00 & 3.00 \\
& Subordination & 15 & 1.00 & .01 & 1.00 & 1.00 \\
\hline Intermediate & Coordination & 15 & 2.60 & 1.40 & 1.00 & 5.00 \\
& Subordination & 15 & 2.35 & 1.15 & 1.00 & 5.00 \\
\hline Advanced & Coordination & 15 & 2.13 & 1.35 & 1.00 & 5.00 \\
& Subordination & 15 & 3.26 & 1.16 & 2.00 & 5.00 \\
\hline
\end{tabular}

Table 11. Descriptive Tables of C-units' Sub-division in Speaking between \& within Groups (Micro)

\begin{tabular}{|c|c|c|c|c|c|c|}
\hline Group & $F$ & Sig & $\begin{array}{c}\text { Micro } \\
\text { categories }\end{array}$ & $\begin{array}{l}\text { Sum of } \\
\text { Squares }\end{array}$ & $\mathrm{df}$ & $\begin{array}{l}\text { Mean } \\
\text { square }\end{array}$ \\
\hline \multirow[t]{3}{*}{ Coordination } & \multirow{3}{*}{1.904} & \multirow{3}{*}{.162} & $\begin{array}{l}\text { Between } \\
\text { groups }\end{array}$ & 5.644 & 2 & 2.822 \\
\hline & & & $\begin{array}{l}\text { Within } \\
\text { groups }\end{array}$ & 62.267 & 42 & 1.483 \\
\hline & & & Total & 67.911 & 44 & \\
\hline \multirow[t]{3}{*}{ Subordination } & \multirow{3}{*}{8.677} & \multirow{3}{*}{.001} & $\begin{array}{l}\text { Between } \\
\text { groups }\end{array}$ & 20.235 & 2 & 10.117 \\
\hline & & & $\begin{array}{l}\text { Within } \\
\text { groups }\end{array}$ & 36.148 & 31 & 1.166 \\
\hline & & & Total & 56.382 & 33 & \\
\hline
\end{tabular}

Comparing the results in the final part, it can be seen that only subordination usage needs to be further analyzed differences among three groups via Multiple Comparisons Tukey HSD to determine the differences among three groups meticulously. The results are provided in table 12.

Table 12. Multiple Comparisons Tukey HSD among 3 Groups in Speaking (Micro)

\begin{tabular}{cccc}
\hline Category & Group & Mean difference & Sig \\
\hline Subordination & $\begin{array}{c}\text { Elementary \& } \\
\text { Intermediate } \\
\text { Elementary \& } \\
\text { Advanced } \\
\text { Intermediate \& } \\
\text { Advanced }\end{array}$ & $-2.04^{*}$ & .028 \\
& $-2.18^{*}$ & .000 \\
\hline
\end{tabular}

*. The mean difference is significant at the 0.05 level.

The more surprising aspect of the data is that no significant differences were identified between the elementary group \& intermediate group and Journal on English as a Foreign Language, 8(1), 75-96 Copyright @ 2018 by JEFL, p-ISSN 2088-1657; e-ISSN 2502-6615 
intermediate group \& advanced group in terms of coordination (Sig $=0.162>$ 0.05). In contrast, the difference between the elementary group \& advanced groups in using subordination was significant ( $\mathrm{Sig}=0.001<0.05)$.

Taken together, these results suggest that there are interesting similarities and differences in macro and micro divisions in Iranian students' English writing and speaking. The next section, therefore, moves on to discussion of these results.

\section{DISCUSSION}

The first question in this study is sought to determine the frequency of Tunits in Macro structures in Iranian students' English writing. As mentioned in the literature review, T-units in Macro structure contain a clause, sentence, and T-unit. As table 1 shows, Iranian students used all these elements in their writing, though there were differences in terms of frequency of occurrence. The findings indicated that in all of these groups, clauses (Mean=18.24) were used as the most frequent part of speech, followed by T-units (Mean=13.80), and sentences (Mean=10.82). According to tables $2 \& 3$, the distinctions in using these parts of speech are evident between elementary \& advanced groups and between intermediate \& advanced groups. The results showed that this difference is because of higher usage of clause (Mean= 24.86), sentence (Mean=15.13) and T-units (Mean=24.20) in advanced group in comparison to other groups. Despite this, no difference was observed between elementary \& intermediate groups since the usage of the clause, sentence, and T-units were approximately similar in these two groups. A possible explanation for this can be increased use of clauses and sentences from elementary to advanced level that indicates the improvement towards more complex structures; this might be a good sign to reflect the proficiency level. However, this cannot always be valid; in line with the research done by $\mathrm{Lu}$ in 2011, as students sometimes try to influence the interviewer, so they use too many unnecessary complex structures, such as applying more than two relative clauses within a sentence, which might result in addressee's confusion.

The second question in this research was to specify the probable significant differences in using T-units in different levels of Iranian learners' English writing in micro structure. Having discussed in previous sections, Tunits in micro level include coordination, subordination, and complex T-unit. Table 4 illustrates the difference in using these subcategories in Iranian students' English writing. The most interesting finding was that coordination $($ Mean $=6.59)$ at all levels of proficiency was the most frequent subcategory in micro level in writing, while the subordination $($ Mean=4.09) and complex T-unit (Mean=3.89) received the second and third positions, respectively. In 
answering the first question of the present study, it had been stated that using structural complexity might not necessarily mirror the proficiency of the learner. The findings of this study are in line with this claim, since the mean length of coordination is higher than subordination. It is a highly held view that subordination in writing reveals complexity (see, e.g., Hopper \& Traugott, 2003; Willis, 2003).

Moreover, high usage of coordination is typically observed in less proficient learners. There are two possible explanations for this result: first, learners, especially in lower levels of proficiency are less exposed to complex structures which justify the little usage of subordination and second, the mean length of the sentence indicates the complexity of the structures and in this regard, coordination seems the easiest way to connect the sentences to increase the length of the sentence. However, contrary to expectation, the mean length of coordination was higher in comparison to subordination which is indicative of weakness and lack of proficiency among advanced Iranian students who were supposed to apply means other than coordinate conjunctions.

Nonetheless, the advanced learners' ineptitude seem to suggest that the problem might be due to the fact that writing is a complicated task and as Luchini (2010) believed, needs plenty of cognitive and linguistic schemes which in most situations are unknown to Iranian learners who are trying to deal with English as a foreign language. The possible explanation for this matter is that Iranian EFL teachers might not provide adequate opportunities to focus on different aspects of teaching syntactic structures and just simply concentrate on introducing the grammatical points and would not allocate time for students to fully understand that. As an instance, while checking the writing papers, the raters mentioned that there were instances in the writings that showed the Iranian students still have difficulties in using English subordinating conjunctions. In other words, as an example, a student preferred to write a series of sentences instead of using subordination connecters.

Example: I study hard. I want to go to a top-rated university to become a doctor.

My parents want me to become a teacher.

The preferred complex sentence:

(1) I study hard because I want to go to a top-rated university to become a doctor, but my parents want me to become a teacher.

(2) Eventhough my parents want me to become a teacher, I study hard because I want to go to a top-rated university to become a doctor. 
Based on the data in the table 6 there is a significant difference in using T-units sub-classifications between elementary group \& intermediate group and between elementary group \& advanced group, while there was no significant distinction between intermediate group \& advanced group. In spite of similarity in using coordination in different levels of proficiency, the types of coordinating conjunctions were totally different. These results are consistent with findings of Bergman and Abrahamsson (2004) who claimed that beginners use simple linking elements, intermediates apply more complex structures and advanced leaners use a wide range of structures in comparison to other levels of proficiency. Among Iranian elementary learners, the most frequent English conjunctions used to connect sentences together were "and" and "but". The reasonable explanation for this matter is that they were only aware of these simple kinds of conjunctions.

Example (1): I need to know how to read and write and to help my country.

Example (2): People learn a lot at university and they become a better person ${ }_{L}$ but they cannot find a good job.

Using more complex coordinating conjunctions such as "so, yet, for, while" in intermediate students' writing displays a improvement in language learning, yet they were still traces of inadequacies as there was no sign of more complex types of coordinating conjunctions.

Example (1): People attend university for they need to learn more and become familiar with their surrounding environment in a more scientific way.

Example (2): Nowadays, people prefer to attend university because they think that can find a better job, so they can support they family.

However, as expected, the English writing of Iranian advanced learners contained different types of complex coordinating conjunctions such as cumulative conjunction, adversative conjunction, and alternative conjunction.

Example (1): Some of the students not only take everything for granted, but also encourage others to do so.

Example (2): Despite the little chance of gaining a good job, some people still prefer to continue their education.

Example (3): After receiving their diploma, students will either enroll in a university or build a career. 
Another difference found in these three groups was in the case of using subordination which would be according to the number of dependent clauses. As shown in table 4, elementary group $(\mathrm{M}=0.87)$ was different from the other two groups, as the usage of subordination was noticeably low, while this range in intermediate group $(\mathrm{M}=3.86)$ was higher and the mean length of subordination application $(M=6.06)$ increased in the advanced group. This finding is consistent with the observations in an earlier study of Norris and Ortega (2009) that stated there might be a boost in using subordinate clauses among intermediate and advanced students that signals complexity in writing. The dependent clauses used in Iranian learners' English writing were divided into finite and non-finite types (Biber and Gray, 2016, p. 63-64). The finite category includes causative clauses, conditionals, and relative clauses, whereas the non-finite category contains an infinitive clause, gerundive and passive clauses. In the elementary group, as mentioned earlier, subordination was rarely used and the sentences mostly consisted of causative and infinitive clauses.

Example (1): I will attend the university because I need more information about everything.

Example (2): I want to go to university and I really like to study more and to go to foreign countries.

In the intermediate group, there seems to be improvement in using subordinate clauses such as conditionals, mostly the first type, causative clause, mostly with "because" similar to the elementary group, relative clauses, mostly with "that" and "which", and very few cases of passive structures. These results can be explained by the fact that students of intermediate level willingly stick to the little amount of their simple and insufficient background knowledge that they have learnt in the school or language institute; enabling them to answer teachers' questions, as long as they do not make a mistake. Unfortunately, some of Iranian EFL teachers encourage this behavior by neglecting the usage of simple structures by an intermediate level student who is supposed to use far more complex structures that he/she has been exposed to. Little use of passive structures and hold to the first type of conditionals are two instances of this problem.

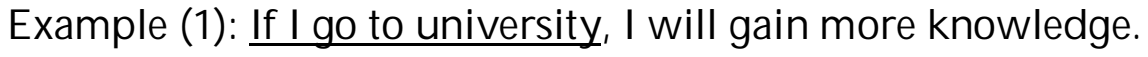

Example (2): It is expected from a high school student to attend university entrance examination, which is very difficult. 
Example (3): Some professors at university inspire their students in a way that it might encourage them to continue their education.

The raise in mean length of using subordinate clauses illuminate the fact that Iranian advanced learners attempt to show a higher level of proficiency by using finite and non- finite types of dependent clauses in their English writing. This finding corroborates the ideas of Celce-Murcia (2002) who suggested that excellence and fluency of a learner in grammar can be discerned when they understand when, where and how to use the correct and various forms of structures.

Example (1): I am a university student now, and sometimes I think that If had studied more, I would have been accepted in a better university.

Example (2): Graduating from university could have been a valuable accomplishment, yet I failed because of my irresponsibility and ignorance.

Example (4): The fact that most of the students are willing to go to another country to continue their education explains the decrease in the number of students who attend universit entrance examination.

The final factor in T-units' subdivision was complex T-units which were not used by elementary students at all, while intermediate learners $(M=2.41)$ and advanced learners $(M=5.46)$ used them in their writing. Complex T-units are made up of an adverbial phrase, prepositional phrase, attributive adjectives and an appositive noun phrase (Biber and Gray, 2016, p. 63-64). The adverbial phrase and prepositional phrases were the most frequent phrases in intermediate and advanced learners' writing, whereas appositive noun phrases were only observed in advanced writings.

Example (1): In the university, students learn more about ethical and morality issues.

Example (2): Two of my professors at university, Mr. Ahmad \& Ms. Jallili, believed we would achieve everything as long as we try.

Example (3): it needs a tremendous practice to get accepted in university. 
The third question of this study aimed to demonstrate the frequency of C-units in different levels of Iranian learners' English speaking in macro structure. Having discussed earlier, C-units in macro level consist of a clause, sentence, and C-unit. According to the table 7, Iranian learners in all of the levels of proficiency of English used clauses $(\mathrm{M}=7.13)$ as the most frequent element in their speech, followed by sentences $(M=5.62)$ and $C$-units $(M=4.08)$. Based on table 8 , the findings of this research, show that there are differences between elementary \& intermediate groups and between elementary \& advanced groups, whereas no difference was found between intermediate \& advanced groups in terms of using macro level sub-divisions of C-units among Iranian EFL students. As table 6 illustrates the average length of using clause in intermediate level $(M=8.93)$ and advanced level $(M=8.0)$ is really close, while this number decreases significantly in elementary level $(M=4.26)$. A likely explanation is that in intermediate and advanced level students are more fluent and are exposed to more application of syntactic complexity based on their book in contrast to elementary learners.

The final question of the study seeks to detect the probable significant differences in using C-units in different levels of Iranian learners' English speaking in micro structure. As mentioned before, C-units in micro level contains coordination and subordination. Based on the data in the table 9, all these three groups used coordination and subordination units in their speaking. According to table10, the usage of coordination in all levels of proficiency was similar. Moreover, table 11 showed that the only significant difference was in using subordination clauses between elementary \& advanced groups, while no significant difference was observed between elementary \& intermediate groups and between intermediate \& advanced groups. Nevertheless, there seems to be inconsistency in the way Iranian students applied English subordination units. In elementary level, the usage of subordinated clause, as expected, was apparently low $(\mathrm{M}=1.00)$, while this number increased $(\mathrm{M}=3.26)$ in advanced level students. These findings further support the study of Bergman and Abrahamsson (2004) who stated that at the advanced level, it is expected to notice an increase in using various types of structures, particularly dependent clause.

Example (1): Some people just decide to go to universities to get further education, to improve their perspectives or to increase the chance of getting a better job position \& higher salary.

Example (2): A: Have you ever thought about continuing your education? B: yes, about a year. 
In general, it seems that on the one hand, due to lack of motivation in Iranian learners, writing in another language becomes a difficult task. This is evident in students' writing by using a simple and repetitive range of vocabularies and/or incapability in producing some complex structures such as passive forms and unreal conditionals. On the other hand, speaking also might appear strenuous because of long-established teacher-oriented methods which lead to far too short opportunities for students to speak in class and/or might be due to the inadequate concentration on developing oral proficiency in the syllabus. However, it seems that the Iranian students might achieve writing goals during their learning procedures compared to speaking, as they have more opportunities to write rather than to speak in an outdoor environment. The findings of this study are consistent with this claim, as it manifested by the high average length of T-units $(\mathrm{M}=13.80)$ in writing, in contrast to low average length of C-units $(\mathrm{M}=4.80)$ in speaking. The results of the current study confirmed Baron's (2000) "Opposition View" that claimed there could be differences in modes of language production such as formal, explicit and complex structures in writing, whereas speaking is simple, informal, with too many pauses and hesitations, and unclear boundaries. In future investigations, it might be possible to only focus on the Iranian advanced learners and those syntactic structures that are missing in their English writing and/or speaking in comparison to native speakers.

\section{CONCLUSION}

The present study was designed to determine the syntactic complexity in different levels of proficiency in Iranian learners' English writing and speaking. The instruments used for measuring the complexity of grammar were T-units for writing and $\mathrm{C}$-units for speaking.

This study shows that there are similarities and differences in applying complex syntactic structures in both writing and speaking. In Iranian learners' English writing, one of the significant findings of this study was the similarity in using clauses as the most frequent element in the macro level, despite the different levels of proficiency. In the micro level, the obtained data shows significant differences between elementary group \& intermediate group and between the elementary group and advanced group, where there seemed to be no significant differences between intermediate group \& advanced group. The second major finding was related to speaking skill which showed a similar pattern to writing in using clauses as the most frequent part of speech on all three levels, whereas there were distinctions between different levels of proficiency in micro level. As the results indicated, there was a significant 
difference between elementary group \& advanced group in using subordinate clauses in speaking.

The current study has gone some way towards enhancing our understanding of grammatical complexity in Iranian students' English learning procedure. A limitation of this study is that the number of subjects was limited and therefore the findings need to be generalized cautiously. More information on this matter can help us to establish a more accurate view on syntactic complexity. A future study investigating the syntactic complexity in reading skill, particularly among Iranian advanced learners is recommended.

\section{REFERENCES}

Ameri-Golestan, A. (2013). Structural priming effects on EFL production of passive structures. Journal of Foreign language teaching and research, 1(1), 11-20.

Armstrong, K. M. (2010). Fluency, accuracy and complexity in graded and ungraded writing. Foreign Language Annals, 43(4), 690-702.

Baron, N. (2000). Alphabet to email. London: Routledge.

Beers, S. F., \& Nagy, W. E. (2011). Writing development in four genres from grades three to seven: syntactic complexity and genre differentiation. Reading and Writing, 24(2), 183-202.

Bergman, P., \& Abrahamsson, t. (2004). Bedömning av språkfärdigheten hos andraspråkselever. In K. Hyltenstam and I. Lindberg (eds) Svenska som andraspråk - i forskning, undervisning och samhälle. Lund: Studentlitteratur: 597-626.

Biber, D., \& Gray, B. (2016). Grammatical complexity in academic English: Linguistic change in writing. Cambridge: Cambridge University Press.

Celce-Murcia, M. (2002).Why it makes sense to teach grammar in context and through discourse. In E. Hinkel\& S. Fotos (Eds.), New perspectives on grammar teaching in second language classrooms (pp. 119-134). Mahwah, NJ: Erlbaum.

Connors, R. J. (2000). The erasure of the sentence. College Composition and Communication, 52(1), 96-128.

Domsch, C., Richels, C., Saldana, M., Coleman, C. Wimberly, C., \& Maxwell, Z. (2012). Narrative shift and systematic complexity in school age children with and without late language emergence. Journal of PubMed, 47(2), 192207.

Hinkel, E. (2003). Simplicity without elegance: features of sentence in L1 \& L2 academic texts. TESOL Quarterly, 37(2), 275- 301.

Hopper, P. J., \& Traugott, E. C. (2003). Grammaticalization. Cambridge: Cambridge University Press. 
Javidnia, A., \& Mahmoodi, K. (2015). The relationship between metalinguistic knowledge (syntax) and Iranian intermediate EFL learners' writing performance. International Journal of Educational Investigations, 2(1), 103120.

Khodabandeh, F., Jafarigohar, M., Soleimani, H., \& Hemmati, F. (2013). Overall rhetorical structure of students' English and Persian argumentative essays. Theory and Practice in Language Studies, 3(4), 684-690.

Larsen-Freeman, D. (2006). The emergence of complexity, fluency and accuracy in the oral and written production of five Chinese learners of English. Applied Linguistics, 27(4), 590- 619.

Low, E. L. (2010). English in Singapore and Malaysia: Similarities and differences. In A. Kirkpatrick (Ed.), Rutledge handbook for world Englishes (pp: 229-46). London: Rutledge.

$\mathrm{Lu}, \mathrm{X}$. (2010). Automatic analysis of syntactic complexity in second language writing. International Journal of Corpus Linguistics, 15(4), 474-496.

$\mathrm{Lu}, \mathrm{X}$. (2011). A corpus-based evaluation of syntactic complexity measures as indices of college-level ESL writers' language development. TESOL Quarterly, 45(1), 36-62.

Luchini, P. L. (2010). Evaluating the effectiveness of a complimentary approach to teaching writing skills. International Journal of Language Studies (IJLS), $4(3), 73-92$.

Maxweel, J. A., \& Loomis, D. M. (2003). Mixed method design: An alternative approach. In A. Tashakkori \& C. Teddlie (eds.), Handbook of mixed methods in social and behavioral research. Thousands Oaks, Calif.: Sage.

Mehregan, M. (2013). Acquiring English language prepositions by Iranian EFL learners: The effect of proficiency and gender. Journal of Studies in Learning and Teaching English, 1(3), 41-57.

Moghtadi, L., Koosha, M., \& Lotfi, A. R. (2015). Learning of relative clauses by L3 learners of English. Applied Research on English Language, 4(1), 79- 105.

Mohammadi, H., Gorjian, B., \& Pazhakh, A. (2014). The effect of classroom structure on speaking skills of Iranian EFL learners: A comparative study. International Journal of Language Learning and Applied Linguistics World (IJLLALW), 5(1), 472-487.

Norris, J. M., \& Ortega, L. (2009). Towards an organic approach to investigating CAF in instructed SLA: The case of complexity. Applied Linguistics, 30(4), 555-578.

Rimmer, W. (2008). Putting grammatical complexity in context. Literacy, 42(1), 29-35. 
Taguchi, N., Crawford, W., \& Wetzel, D. Z. (2013). What linguistic features are indicative of writing quality? A case of argumentative essays in a college composition program. TESOL Quarterly, 47(2), 420-430.

Willis, D. (2003). Rules, patterns and words: grammar and lexis in English language teaching. Cambridge: Cambridge University Press.

\section{Author's Brief CV}

Sarah Yazdani is a Ph.D. candidate at the department of Linguistics, Faculty of Letters and Humanities, Ferdowsi University of Mashhad, Iran, where she carries out comparative studies on linguistic issues in languages such as Persian, English and Italian. At the moment, she is working towards becoming a neurolinguist. She hopes to work particularly with dementia patients. 